\title{
The scheme comparison about the foundations of shear wall structure in Yellow River Delta region
}

\author{
Zhaojun Ren, Hongsheng Yu, Xiuyan Zhang, Xia Zhao, Na Li \\ ${ }^{1}$ Binzhou Polytechnic, Binzhou 256603, China \\ 13769055@qq.com
}

Keywords: The Yellow River Delta, the foundation scheme, the comprehensive evaluation and comparison.

\begin{abstract}
The selection of the building foundation is a comprehensive project which is deeply affected by the different region. Based on the typical geological structures and engineering examples, the paper analyzes and compares the three basic types of shear wall structures from the aspects of the bearing capacity, the engineering cost, the construction engineering, the construction technology and the effect to the environment around. By comparison, there comes a scheme of technical feasibility, safety, reliability and economic rationality. It provides a good basis for the selection of shear wall structure in the Yellow River Delta region.
\end{abstract}

\section{Introduction}

The technology of the foundation design is relatively mature in domestic. For there is a difference between the quality of materials, the construction technology and the climate characteristics in different region, it is necessary to analysis the design of the building foundation. The geographical position of the Yellow River delta is unique. It is the main battlefield of national economic development. With the rapid increase in the scale of construction planning and construction speed, what confuses the entire construction industry is that which kind of building foundation type is the most economical. Therefore, aimed at the type of building foundation structure shear wall, the author researches the most suitable building foundation types in the Yellow River Delta region. Based on the engineering examples, the paper makes the economic and technical analysis. It will play a great role in promoting the economic development of the Yellow River Delta region, and even in the national building foundation of the optimization and selection work.

\section{Project profile}

The form of the project is shear wall structure. Mezzanine structure is made up of underground storage which is made of 1-story underground storeroom, 11-story apartment and a machine room. The building is 42.82 meters long in the east-west, 13.40 meters wide in the north-south, and the level difference is 1.40 meters between indoor and outdoor. The height of the building is 34.40 meters (from ground outdoor to main roof gutter). The gross area is 6583.94 square meters.

The geomorphic type of planning to build engineering worksite is alluvial flat in the Lower Yellow, the terrain is relatively flat. Elevation of the orifices is even and the biggest height difference is 0.11 meters. There are no bad geological phenomena in the proposed field what might affect stability of the site. There is no active fault new zone nearby. The regional geological environment is relatively stable. 


\section{The site environment and geological engineering conditions}

\subsection{Topographic and geomorphic conditions}

The terrain of the proposed field is relatively flat. The Elevation of measuring parts are between 8.52 meters and 9.44 meters. The biggest Level difference is 0.92 meters. The geomorphic type of this area is alluvial flat in the Lower Yellow.

\subsection{The surrounding environment}

The distance from the east of the planned projects to the 4-storey ongoing building (with pile foundations) is 10.00 meters. It is 40.00 meters from its west to Binbo Avenue and it's north to Six Longteng Road, and it's empty in the south.

\subsection{Stratigraphic structure}

According to field drilling, the field test data and the indoor soil test, the foundation soil of the proposed field can be divided into 14 layers (see Table 1).

Table 1: Stratigraphic structure

\begin{tabular}{lccccccc}
\hline Layers & 1 & 2 & 3 & 4 & 5 & 6 & 7 \\
\hline Soil & silt & clay & silt & silty clay & silt & silty clay & silt \\
Layers & 8 & 9 & 10 & 11 & 12 & 13 & 14 \\
Soil & silts & silty clay & silt & silty clay & silt & silty clay & silt \\
\hline
\end{tabular}

\section{Foundation scheme analysis}

\subsection{Evaluation of the natural foundation}

According to geotechnical investigation descriptions, the proposed building F1 F3、F5 F8 are the 11+1-storey shear wall structure without the underground storeroom. The foundation embedded depth is 3 meters. Using standard combinatorial of load effect, the unitload estimated are $210 \mathrm{kPa}$ and $310 \mathrm{kPa}$. The foundation schemes of these proposed projects are analyzes the following:

Analyzed the survey data, with geotechnical section, the bearing stratum of the proposed building F1 $\sim$ F3F5 F8 is silt soil, The bearing capacity characteristic value is $95 \mathrm{kPa}$, if considered it as raft foundation, the value rose to $174 \mathrm{kPa}$. The results show clearly that the bearing capacity can not satisfy the need, so it would be inappropriate to use the solution of raft foundation.

\subsection{The initial design of three tentative scheme}

Analyzed the characteristics of the project, we found the best scheme includes prestress concrete pipe piles,(shown in Fig.1), Prefabricated prestressed squared piles and cement Fly-ash gravel pile(CFG pile foundation)through the geotechnical analysis of the site.

Project 1: 400 Prefabricated prestressed squared piles 


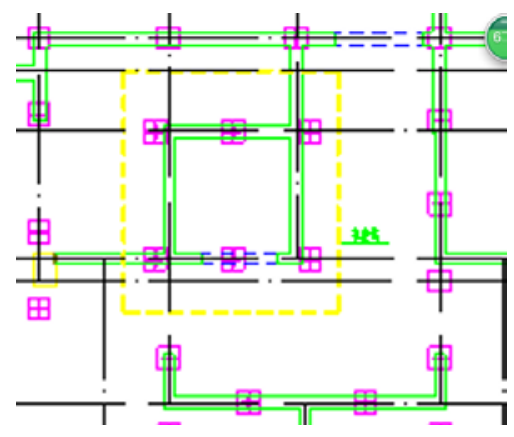

Fig. 1 The floor plan of the 400 Prefabricated prestressed squared piles

Prefabricated prestressed squared piles L12SG09_PHS-AB-400(220)-22.

The eigenvalue of the pile foundation's vertical bearing weight is $\mathrm{Ra}=1000 \mathrm{KN}$ (The results based on the dead load experiment.

The relative elevation of pile-top is $-3.550 \mathrm{~m}$ (the elevation is determined at the interior reference point).

Project 2:400 prestress concrete pipe piles(shown in Fig.2).prestressed concrete pipe piles L06G407_PHC-A400 ( 95) - ( 22 ).

The eigenvalue of the pile foundation's vertical bearing weight is $\mathrm{Ra}=780 \mathrm{KN}$ ( The results based on the dead load experiment ) .

The relative elevation of pile-top is $-3.550 \mathrm{~m}$ (the elevation is determined at the interior reference point), The relative elevation of pile-top in the thick dotted scope is $-5.050 \mathrm{~m}$.

Project 3 : CFG pile foundation(shown in Fig.3).

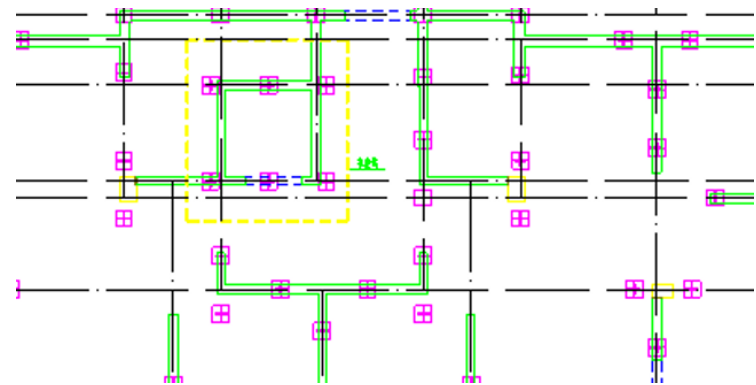

Fig. 2 concrete pipe piles

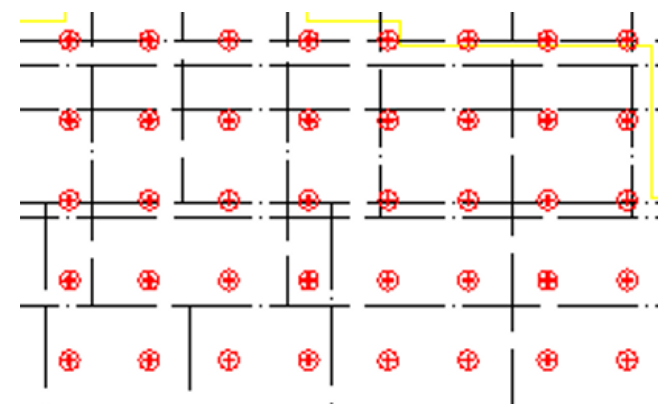

Fig. 3 CFG pile foundation

The diameter of the plain concrete (CFG) pile is $500 \mathrm{~mm}$, the length is $15.00 \mathrm{~m}$, the relative elevation of pile-top is $-3.7 \mathrm{~m}$. The pile bearing layer is in the fifth layer silt, the concrete grad is C25.The bearing capacity of the composite foundation with treatment is 220Kpa.On the top of the pile there are $200 \mathrm{~mm}$ thick mattress layer which layered 5-20mm graded broken stone, the compacting factor is not less than 0.9 .

\subsection{The techno-economic analysis of the foundation schemes}

\subsubsection{Capacity analysis}

(1) Cement Fly-ash Gravel pile (CFG pile)

The design parameter of Cement Fly-ash Gravel pile (CFG pile) composite foundation according to Technical specification of the treatment of buildings foundation ( JGJ79-2002) are

shown in the following table 2. 
Table 2: Table of the design parameter of Cement Fly-ash Gravel pile

( CFG pile) composite foundation

\begin{tabular}{cccc}
\hline Soils & $\begin{array}{c}\text { Ultimate flank friction } \\
\text { eigenvalues of piles } \\
\mathrm{q}_{\text {sik }}(\mathrm{kPa})\end{array}$ & $\begin{array}{c}\text { Thebearing capacity } \\
\text { eigenvalues of the } \\
\text { inter-pile soils } \\
\mathrm{f}_{\mathrm{ak}}(\mathrm{kPa})\end{array}$ & $\begin{array}{c}\text { The resistance } \\
\text { eigenvalues of the pile-end } \\
\mathrm{Q}_{\mathrm{pk}}(\mathrm{kPa})\end{array}$ \\
\hline 1layer silts & 20 & 95 & \\
2layer clay & 20 & 90 & \\
3laver silts & 21 & & \\
4layer silty clay & 21 & & 450 \\
4-1layer silts & 20 & 400 \\
5layer silts & 22 & 450 \\
61layer silty clay & 21 & & \\
7layer silts & 23 & & \\
\hline
\end{tabular}

Note: The data in the table is only for preliminary design.

In the primary project, the arrangement of the piles could be a square. The distance between the piles is $2.00 \mathrm{~m}$, and the diameters are $\varphi 500 \mathrm{~mm}$, the bearing stratum at the tip of piles is 5layer silt. The treatment depth is $18.00 \mathrm{~m}$ ( the top elevation of piles

are considered as $6.00 \mathrm{~m}$, the bottom elevation are considered as $-9.00 \mathrm{~m}$, pile net length is $15.00 \mathrm{~m}$ ) .The bearing capacity of the composite foundation with treatment is 220Kpa.It would be appropriate to use the solution of raft foundation if the bearing layer is the composite foundation through treatment.

(2)Prefabricated prestressed squared piles and prestressed concrete pipe piles

The relevant design parameters of the prefabricated prestressed squared piles or prestressed concrete pipe piles according to Design of Building Foundation (GB50007-2011) and Technical code for building pile foundation (JGJ94-2008) are shown in the following table 3 .

Table 3: The design parameters of the prefabricated prestressed squared piles and prestressed concrete pipe piles

\begin{tabular}{|c|c|c|}
\hline Soils & $\begin{array}{l}\text { The standard values of } \\
\text { ultimatelateral resistance } \\
\text { qsik }(\mathrm{kPa})\end{array}$ & $\begin{array}{c}\text { The standard values of ultimate } \\
\text { end bearing resistance } \\
\text { qpk ( } \mathrm{kPa})\end{array}$ \\
\hline 1layer silt & 32 & \\
\hline 2layer clay & 44 & \\
\hline 3layer silt & 42 & \\
\hline 4layer silty clay & 42 & 800 \\
\hline 4-1layer silt & 42 & \\
\hline 5layer silt & 52 & \\
\hline 6layer silty clay & 55 & \\
\hline 7layer silt & 62 & 2500 \\
\hline 8layer silty sand & 67 & 3000 \\
\hline
\end{tabular}

Note: 1: The data in the table is only for test piles design estimates. The 2:1 layer silt has liquefaction potential, 2/3 can be chosen as the deduction factor.

If the bearing stratum at the tip of piles is 7layer silt, The treatment depth is $24.00 \mathrm{~m}$ ( the top elevation of piles are considered as $6.00 \mathrm{~m}$, the bottom elevation are considered as $-15.00 \mathrm{~m}$, pile net length is $21.00 \mathrm{~m}$ ) . The normal value of ultimate bearing capacity of PHC piles are about 
$1939 \mathrm{kN}$ to $2011 \mathrm{kN}$, and the bearing capacity characteristic value of single piles were estimated as $950 \mathrm{kN}$ according to Technical code for building pile foundation (JGJ94-2008), and the pile diameter of PHC piles is $500 \mathrm{~mm}$. The normal value of ultimate bearing capacity of PHC piles are about $1968 \mathrm{kN}$ to $2023 \mathrm{kN}$, and the bearing capacity characteristic value of single piles is estimated as $950 \mathrm{kN}$ if using 400 x 400 prefabricated prestressed squared piles.

\subsubsection{The possibility of the piling and its influence on environment}

(1) Cement Fly-ash Gravel pile (CFG pile)

The CFG pile can be using the long spiral to realize the pump transport and concrete agitation continuously. This construction technological process has such advantages as quick construction rate, short time limits and low construction price. Many more factors come into construction technologies of the piles such as some sections of 4layer silty clay has plasticity.

This process is suitable with small impact to the surrounding environment, low noise, no slurry and spoil is easy to handle.

(2) Prestressed piles or Prefabricated squared piles

The pile-sinking construction can be implemented by impact or static pressure method. This construction technological process has such advantages as quick construction rate and short time limits. Many more factors come into construction technologies of the piles such as compacted soil. This process is suitable with small impact to the surrounding environment, low noise and no slurry.

\subsubsection{Economic analysis and comparison}

So the ratio of the cost of the bearing capacity per volume to the total cost of a single project is the most scientific indicator to measure economic benefit of pile foundation, instead of the ratio of the cost per meter to the cost per unit concrete. Based on the report of geotechnical investigation and project experience of the project, we analyzed three pile types which most likely be applied.

\subsubsection{Comprehensive analysis of construction}

The economic benefit directly affected by the construction period. Shorten construction duration can bring a lot of benefits, such as lower interest and management costs. More importantly, the proprietor can get better market timing. The construction period and composite analysis of foundation construction with conventional method.

\section{Conclusions}

For its particularity of geological structures and the tight connections between foundation and areas, which kind of building foundation is the most suitable type for the region's floodplains has been affected the development of Binzhou's building industry. This paper combined the foundation scheme of one high-rise building, considered the super structure and geologic condition, and analyzed three preliminary design scheme of the prefabricated prestressed squared piles, the prestress concrete pipe piles and the CFG pile foundation. This thesis on technical \& economical comparison has come to the following conclusions:

(1)It has been found out that the prefabricated prestressed squared piles and prestress concrete pipe piles superior to CFG pile foundation by analyzing bearing capacity found;

(2)This thesis analyzed feasibility study and the surroundings draw a conclusion that the prefabricated prestressed squared piles and prestress concrete pipe piles are more suitable;

(3)Through the comparative analysis of economic effects, we regard that the total cost of CFG pile is lowest of the three. But considering the bearing capacity per volume of pile, Prefabricated prestressed squared piles is the most economical choice. So the ratio of the cost 
of the bearing capacity per volume to the total cost of a single project is the most scientific indicator to measure economic benefit of pile foundation, instead of the ratio of the cost per meter to the cost per unit concrete.

(4)From the construction period and feasibility degree we find out that the most reasonable pile foundation form is the prefabricated prestressed squared piles.

In conclusion, for this engineering background the prefabricated prestressed squared piles the most economic, dependable method.

\section{Acknowledgements}

Research on green building energy saving design based on BIM modeling

\section{References}

[1]Ministry of Construction of the People's Republc of China. GB50007-2002 Design of Building Foundation [S].Beijing: China's industrialization press, 2002.

[2]Yuan Ding.Pengcheng Sun, Ye Li. Foundation lectotype and economic analysis of a highrise building [J]. Jiangsu construction industry, 2010，(1): 70-73.

[3]Jianfeng Li,Jianguo Luo, Ying Zhang. Comprehensive assessment and selection of the design of high rise building foundations[J].Design and construction,2005, （9）:5-57.

[4]Yanzhong Fan. Technological and economic analysis and selection of the scheme of high rise building foundations.[J]the Journal of University of Science and Technology of Suzhou(engineering technology), 2011, (1):55-58. Program of Shandong Education Department.

[5]JGJ 94-2008, Technical Code for Building Pile Foundations, China Architecture \& Building Press (2008).

[6]GB 50007-2011, Code for design of building foundation, China Architecture \& Building Press (2011) .

[7]JGJ 79-2012, Technical code for ground treatment of bu, China Architecture \& Building Press (2012) .

[8] GB 50009-2012, Load code for the design of building structure, China Architecture \& Building Press (2012) .

[9] L06J002, Construction engineering practice , China Architecture \& Building Press (2006)

[10]Zhang Yunhai, Zhang Xinxing and Zhou Qing. The selection and design of pile foundation in the Yellow River Delta Edited Shanxi Architecture. Vol.37 No. 22, pp. 85-90, 2011.

[11] Qian Lihang. Design and calculation of box and raft foundation of high rise building. Edited China Building Industry Press (2003). 